\title{
The Effect of High Molecular Weight Bio-based Diamine Derivative of Dimerized Fatty Acids Obtained from Vegetable Oils on the Structure, Morphology and Selected Properties of Poly(ether-urethane-urea)s
}

\author{
Marcin Włoch $^{1} \cdot$ Janusz Datta $^{1}$ (D) $\cdot$ Kamila Błażek $^{1}$
}

Published online: 24 June 2017

(C) The Author(s) 2017. This article is an open access publication

\begin{abstract}
In this work, the effect of the high molecular weight bio-based diamine on the chemical structure and selected properties of poly(ether-urethane-urea)s has been investigated. The ether-urethane prepolymer was cured using 1,4-butanediol and/or bio-based diamine. Mentioned chain extenders were used separately or in the mixture, and their different molecular weight and chemical structure resulted in obtaining materials with diversified mechanical performence. The presence of specific chemical groups (i.e. urethane and urea groups) was confirmed by FTIR method. For the synthesized poly(ether-urethane-urea)s morphology and fracture mechanism, thermo-mechanical properties and mechanical properties were determined and discussed. Results confirmed that bio-based diamine acts as soft segments, and this is connected with changing of mechanical and thermo-mechanical properties of prepared partially bio-based poly(ether-urethane-urea)s. The increasing content of bio-based diamine resulted in increasing of tensile modulus and decreasing of tensile strength and elongation at break, and this is resulted from chemical structure of biobased diamine (i.e. presence of aliphatic side chains).
\end{abstract}

Keywords Poly(ether-urethane-urea) $\cdot$ Bio-based diamine $\cdot$ Chemical structure, morphology and properties

Janusz Datta

janusz.datta@pg.gda.pl

1 Department of Polymer Technology, Faculty of Chemistry, Gdańsk University of Technology, G. Narutowicza Str. 11/12, 80-233 Gdansk, Poland

\section{Introduction}

Modern chemistry and technology of polyurethanes is focused on using renewable resources connected with industrial plants, e.g. polyols based on vegetable oils [1-4] glycerol [5] or sorbitol [6], bio-based chain extenders, e.g. corn sugar-based 1,3-propanediol [3, 7, 8], and bio-based diisocyanates synthesized using fatty acids dimers [9] or lysine [10] in the synthesis. In accordance to the literature, the special place is occupied by vegetable oils and their derivatives (e.g. fatty acid dimers) which can be transformed to di- or poly-functional polyols, which are useful in the synthesis of e.g. polyurethanes foams [2, 11, 12], thermoplastic polyurethane elastomers [3] or waterborne polyurethane dispersions [13].

In the area of polyureas, poly(urethane-urea)s and nonisocyanate polyurethanes the main important issue is synthesis of bio-based diamines. Amine-functional compounds can be also derived from natural resources, as e.g. cardanol [14], vanillin [15], pentaerythritol [16], isosorbide [17], isosodide [18], dimers of fatty acids $[19,20]$ and vegetable oils [21]. Examples of bio-based diamines are presented in Fig. 1. The modification of bio-based starting molecules can be easily realized by thiol-ene coupling i.e. reaction between unsaturated monomers and aminothiols [16, 21]. Mentioned bio-based diamines are especially applied as: a curing agent for epoxy resins $[14,16]$, cyclic carbonate intermediates (components for the synthesis of non-isocyanate polyurethanes) $[15,19]$ and as components in the synthesis of polyamides [17] and polyimides [18].

Priamine 1071 produced by Croda (Netherlands) used in this study as a curing agent is bio-based and high purity building block with $100 \%$ renewable carbon. Mentioned diamine, in the terms of chemical structure is an amine derivative of dimerized fatty acids. The fatty acids were 
<smiles>N[C@H]1COC2C1OC[C@H]2N</smiles>

isosorbide-based diamine<smiles>N[C@H]1COC2C1OC[C@H]2N</smiles>
isosodide-based<smiles>C=C(C)OCCCSCCN</smiles><smiles>NCCSCCCOCC(CO)(COCCCSCCN)COCCCSCCN</smiles><smiles>CCCCCCCCC(CCC(C)(C)CC(=O)OCC(COC(=O)CC(C)(C)C)OC(=O)CC(C)(C)C)OC(=O)CCC(CCCCCC)SCCN</smiles>

Fig. 1 Examples of bio-based diamines

obtained from vegetable oil (e.g. soybean oil) by chemical conversion, and Croda produce several different fatty acid dimers from e.g. soybean and sunflower oil. Priamine 1071 was designed as curing agent for epoxy systems. Examples of possible structures (acyclic, cyclic and aromatic) of mentioned bio-based diamine are presented in Fig. 2.

Our earlier work [22] was focused on the poly(ester-urethane-urea)s synthesized using a biobased diamine (PRIAMINE 1071) as a chain extender and chemical structure, mechanical and thermo-mechanical properties of obtained poly(ester-urethane-urea)s were determined. In the chemistry and technology of polymers it is very important to investigate the influence of the selected monomer (chain extender) on the properties of different systems (consisted of different isocyanates and polyols). The interaction between the bio-based diamine moieties and ester- and ether-based polyol main chain is different due to their different chemical structure.

The main aim of this work was to synthesize the poly(urethane-urea)s using a bio-based diamine (obtained from fatty acid dimers) as a single curing agent or in the mixture with 1,4-butanediol. Chemical structure, morphology, thermo-mechanical properties and tensile properties of obtained poly(ether-urethane-urea)s were determined and discussed.

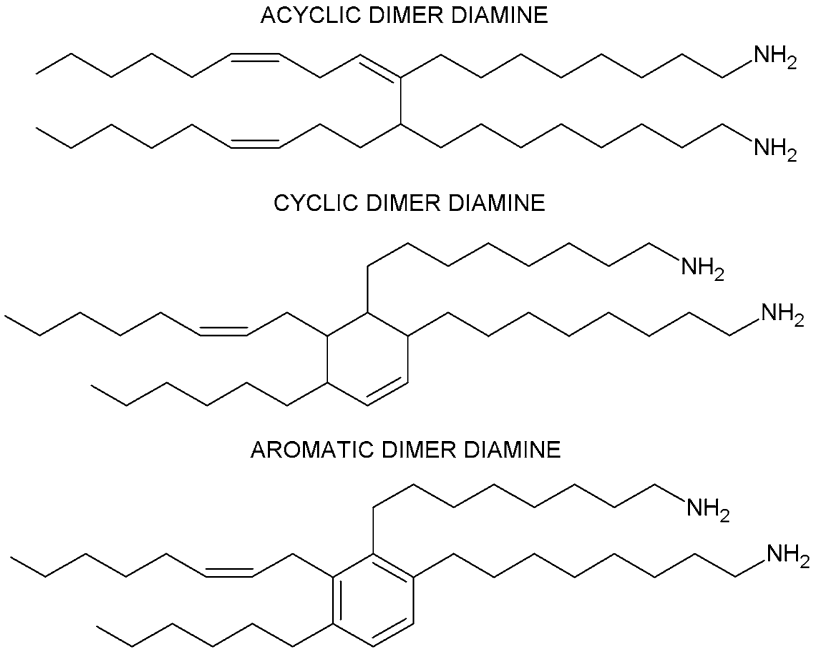

Fig. 2 Possible chemical structures of amine derivative of dimerized fatty acids

\section{Experimental}

Synthesis and Description of Poly(ether-urethane-urea)s

The synthesis of poly(ether-urethane-urea)s was realized by two-step method. In the first step ether-urethane prepolymer 
was synthesized through a reaction between polytetrahydrofurane (PolyTHF, Overlac, Poland; $\mathrm{M}_{\mathrm{w}}=2000 \mathrm{~g} / \mathrm{mol}$, $\mathrm{L}_{\mathrm{OH}}=56 \mathrm{mgKOH} / \mathrm{g}$ ) and 4,4'-diphenylmethane diisocyanate (MDI, Borsodchem, Hungary; $\mathrm{M}_{\mathrm{w}}=250,25 \mathrm{~g} / \mathrm{mol}$ ). The molar ratio of components PolyTHF:MDI was equal $1: 2$, and the reaction was performed in bulk. Reaction was realized at $80^{\circ} \mathrm{C}$, for $2 \mathrm{~h}$, under vacuum. In the next step, prepared prepolymer was extended with using: 1,4-butanediol (BDO, BRENNTAG, Poland; $\mathrm{M}_{\mathrm{w}}=90,12 \mathrm{~g} / \mathrm{mol}$ ), biobased diamine (PRIAMINE 1071, Croda, Netherlands; $\mathrm{M}_{\mathrm{w}}$ $=548 \mathrm{~g} / \mathrm{mol} ; \mathrm{L}_{\mathrm{NH} 2}=205 \mathrm{mg} \mathrm{KOH} / \mathrm{g}$ ) or mixture of both components. The molar ratio of isocyanate to hydroxyl or/ and primary amine groups during chain extending step was 1:1. Formulations of used chain extender agents were presented in Table 1.

The chain extending of prepolymer was realized using Brabender mixer $\left(100^{\circ} \mathrm{C}, 80 \mathrm{rpm}, 6 \mathrm{~min}\right)$, due to high viscosity of reaction mixture, resulted from high reaction rate of isocyanate groups with primary amine groups. After that obtained reaction mass was transferred into metal mould (dimension of mould cavity: $120 \mathrm{~mm} \times 110 \mathrm{~mm} \times 2 \mathrm{~mm}$ ) and pressed using a hydraulic press at $100^{\circ} \mathrm{C}$, under pressure $5 \mathrm{MPa}$ for $15 \mathrm{~min}$ and finally seasoned at $100^{\circ} \mathrm{C}$ for $24 \mathrm{~h}$ to complete curing process in laboratory oven. Synthesis of ether-urethane prepolymer and poly(urethane-urea)s is shown in Fig. 3.

The content of hard segments (HS), soft segments (SS) and bio-based components was presented in Table 2. Inthe case of prepared poly(ether-urethane-urea), coded as PEtUM-1.0BA, soft segments are main constituents (83.6 wt $\%$ ) in the structure and consist of high molecular weight bio-based diamine moieties (PRIAMINE 1071), and high molecular weight linear ether-based polyol (PolyTHF). Hard segments are made up of 4,4'-diphenylmethane diisocyanate (MDI) rest. In the case of materials synthesized using low molecular weight diol i.e. 1,4-butanediol

Table 1 Formulations of prepared polyurethane and poly(urethaneurea)s

\begin{tabular}{|c|c|c|c|c|}
\hline \multirow[t]{2}{*}{ Polymer } & \multicolumn{2}{|c|}{ Synthesis—step I } & \multicolumn{2}{|c|}{ Synthesis-step II } \\
\hline & $\begin{array}{l}\text { PolyTHF } \\
(\mathrm{mol})\end{array}$ & $\begin{array}{l}\text { MDI } \\
(\mathrm{mol})\end{array}$ & $\begin{array}{l}\text { BDO } \\
(\mathrm{mol})\end{array}$ & $\begin{array}{l}\text { PRIAMINE } \\
(\mathrm{mol})\end{array}$ \\
\hline $\begin{array}{l}\text { PEtU } \\
\text { Poly(etherurethane) }\end{array}$ & 1 & 2 & 1 & 0 \\
\hline $\begin{array}{l}\text { PEtUM-0.25BA } \\
\text { Poly(etherurethane-urea) }\end{array}$ & 1 & 2 & 0.75 & 0.25 \\
\hline $\begin{array}{l}\text { PEtUM-0.5BA } \\
\text { Poly(etherurethane-urea) }\end{array}$ & 1 & 2 & 0.5 & 0.5 \\
\hline $\begin{array}{l}\text { PEtUM-0.75BA } \\
\text { Poly(etherurethane-urea) }\end{array}$ & 1 & 2 & 0.25 & 0.75 \\
\hline $\begin{array}{l}\text { PEtUM-1BA } \\
\text { Poly(etherurethane-urea) }\end{array}$ & 1 & 2 & 0 & 1 \\
\hline
\end{tabular}

[as a single chain extender (PEtU) or as a part of chain extenders mixture (PEtUM-0.25BA, PEtUM-0.5BA and PEtUM-0.75BA)] hard segments are composed of 4,4'-diphenylmethane diisocyanate moieties and 1,4-butanediol rest. The difference in molecular weight between 1,4-butanediol and used bio-based diamine results in higher content of hard segments in the case of PEtU in comparison to PEtUM-1.0BA, due to soft nature of high molecular weight bio-based diamine.

\section{Testing Methods}

The presence of chemical groups (e.g. urethane and urea groups) in the chemical structure obtained poly(etherurethane) and poly(ether-urethane-urea)s was confirmed by Fourier Transform Infrared Spectroscopy (FTIR) using Nicolet 8700 FTIR Spectrophotometer (Thermo Electron Co.), and 64 scans was taken between 500 and $4000 \mathrm{~cm}^{-1}$, with the resolution of $4 \mathrm{~cm}^{-1}$.

Chemical structure of bio-based diamine (Priamine 1071) and selected poly(ether-urethane-urea)s was investigated by Hydrogen Nuclear Magnetic Resonance Spectroscopy ( ${ }^{1} \mathrm{H}$ NMR). Spectra were recorded at the room temperature using a Varian Mercury Vx spectrometer operating at frequency of $400 \mathrm{MHz}$ and applying $\mathrm{CDCl}_{3}$ as a solvent.

The surface morphology of selected bio-based poly(ether-urethane-urea)s was analyzed using atomic force microscopy (AFM, Nanosurf EasyScan II) in tapping mode. The AFM micrographs analysis was performed in Gwyddion program.

Dynamic Mechanical Thermal Anaysis (DMTA) was performed with using DMA Q800 Analyzer (TA Instruments). Measurements were realized in the temperature range from -100 to $100^{\circ} \mathrm{C}$, at an operating frequency of $10 \mathrm{~Hz}$, with a heating rate of $4^{\circ} \mathrm{C} / \mathrm{min}$. The samples were $3 \mathrm{~mm}$ thick, $10 \mathrm{~mm}$ wide and $40 \mathrm{~mm}$ long. Storage modulus, loss modulus and damping factor vs. temperature were determined.

Thermal characterization of poly(urethane-urea) was carried out using a DSC 204 F1 Phoenix Analyzer. At first, the sample was heated at a rate of $20^{\circ} \mathrm{C} / \mathrm{min}$ from -80 to $200^{\circ} \mathrm{C}$. In the first cycle, the thermal history of the sample was erased. It was then cooled down to $-80^{\circ} \mathrm{C}$ at a cooling rate of $20^{\circ} \mathrm{C} / \mathrm{min}$, and then heated up to $200^{\circ} \mathrm{C}$ at a rate of $20^{\circ} \mathrm{C} / \mathrm{min}$. The measurements was performed under a nitrogen atmosphere.

Thermogravimetric analysis (TGA) of the selected samples was carried out using NETZSCH TG 209F3 analyzer. The sample has the mass ca. $5 \mathrm{mg}$ and the temperature of measurement was ranged from 40 to $600^{\circ} \mathrm{C}$ with a heating rate of $20^{\circ} \mathrm{C} / \mathrm{min}$ under nitrogen atmosphere. 


\section{STEP I - Synthesis of ether-urethane prepolymer}

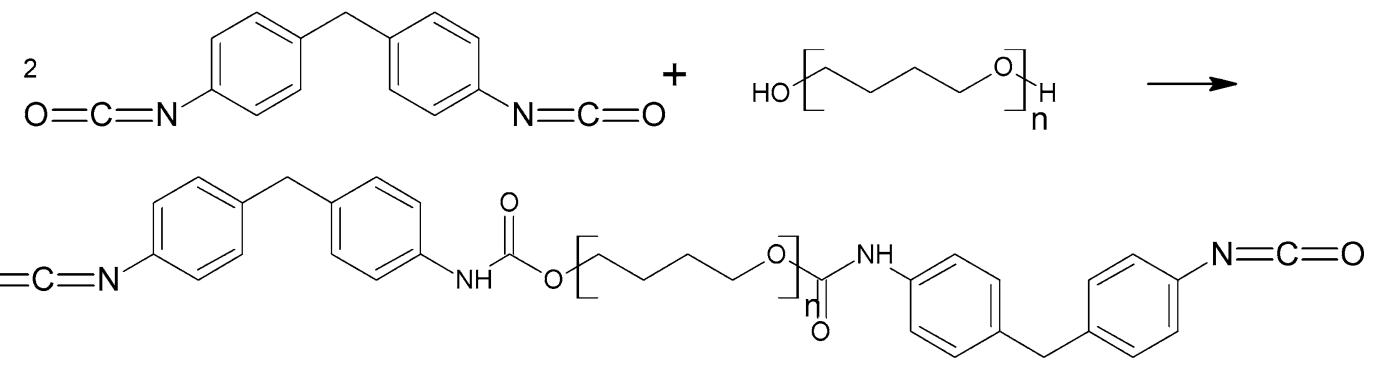

\section{STEP II - Synthesis of poly(ether-urethane) and poly(ether-urethane-urea)s}

Example II-1 Synthesis of poly(ether-urethane) - Reference Sample PEtU

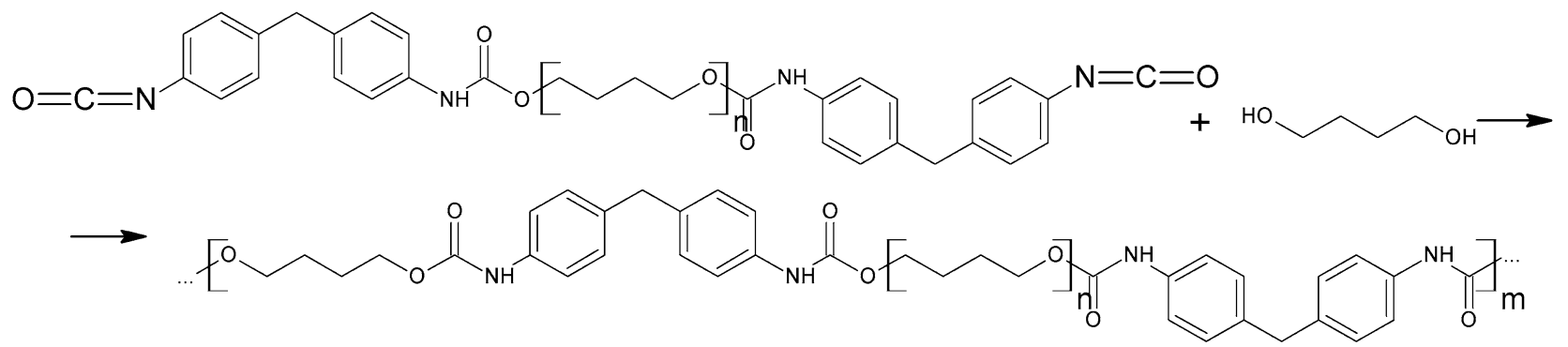

Example II-2 Synthesis of poly(ether-urethane-urea) - Sample PEtUM-0.5BA
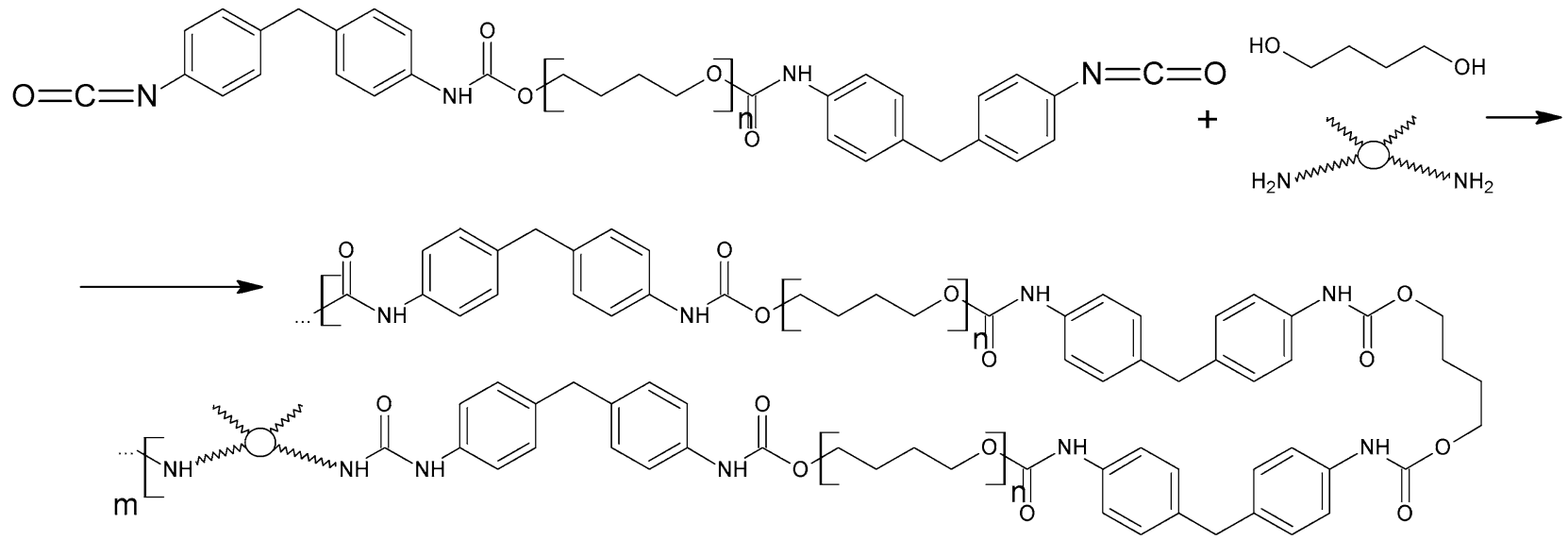

Example II-3 Synthesis of poly(ether-urethane-urea) - Sample PEtUM-1.OBA

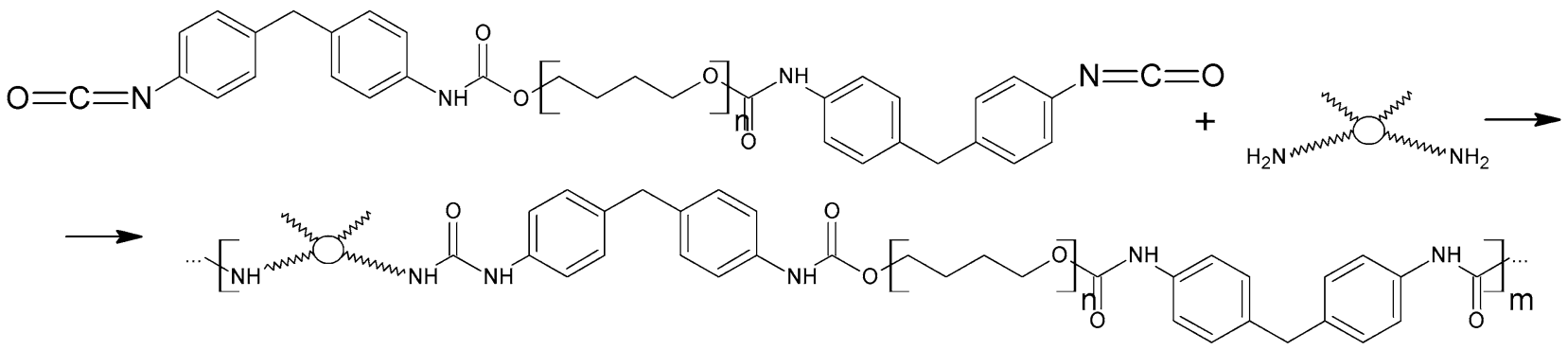

Fig. 3 Synthesis of poly(ether-urethane) and poly(ether-urethane-urea)s 
Table 2 Hard segments, soft segments and bio-based content in the prepared polyurethane and poly(urethane-urea)s

\begin{tabular}{llll}
\hline Polymer & $\begin{array}{l}\text { Hard } \\
\text { segments } \\
\text { content } \\
\text { HS (wt\%) }\end{array}$ & $\begin{array}{l}\text { Soft } \\
\text { segments } \\
\text { content } \\
\text { SS (wt\%) }\end{array}$ & BIO (wt\%) \\
\hline $\begin{array}{l}\text { PEtU } \\
\begin{array}{l}\text { Poly(etherurethane) } \\
\text { PEtUM-0.25BA }\end{array}\end{array}$ & 22.8 & 77.2 & - \\
$\begin{array}{l}\text { Poly(etherurethane- } \\
\text { urea) }\end{array}$ & 21.0 & 79.0 & 5.1 \\
$\begin{array}{l}\text { PEtUM-0.5BA } \\
\begin{array}{l}\text { Poly(etherurethane- } \\
\text { urea) }\end{array}\end{array}$ & 19.3 & 80.7 & 9.7 \\
$\begin{array}{l}\text { PEtUM-0.75BA } \\
\text { Poly(etherurethane- } \\
\text { urea) }\end{array}$ & 17.8 & 82.2 & 14.0 \\
$\begin{array}{l}\text { PEtUM-1BA } \\
\text { Poly(etherurethane- } \\
\text { urea) }\end{array}$ & 16.4 & 83.6 & 18.0 \\
\hline
\end{tabular}

Static tensile properties (tensile strength and elongation at break) were measured with using Universal Testing Machine Zwick/Roell Z020 with cross-head speed equal $100 \mathrm{~mm} / \mathrm{min}$. Static tensile tests were realized according to ISO 527-2. The test samples were prepared in a standard dumbbell shape (with the width around $6 \mathrm{~mm}$ and thickness around $2 \mathrm{~mm}$ ). Recorded results are averages of five independent measurements.
Fracture surfaces after static tensile test were analyzed using desktop scanning electron microscope Phenom G2 PRO (Phenom-World) with accelerating voltage of $5 \mathrm{kV}$.

\section{Results and Discussion}

Analysis of FTIR spectra (Fig. 4) confirm presence of typical chemical groups in the chemical structure of obtained poly(ether-urethane) and poly(ether-urethane-urea)s. The most important bands related to characteristic vibrations of chemical groups are: stretching vibrations of carbonyl group in urethane groups ( $\mathrm{v}=\mathrm{O}$ at $1725 \mathrm{~cm}^{-1}$ ), stretching vibrations of carbonyl group in urea group $(\mathrm{v} \mathrm{C}=\mathrm{O}$ at $\left.1625 \mathrm{~cm}^{-1}\right)$, stretching vibrations of $\mathrm{C}-\mathrm{N}$ in amide group [v $\mathrm{C}(\mathrm{O}) \mathrm{NH}$ at $1525-1535 \mathrm{~cm}^{-1}$ ], stretching (v $\mathrm{C}-\mathrm{O}$ at 1165 and $\left.1138 \mathrm{~cm}^{-1}\right)$ and bending $\left(\delta \mathrm{C}-\mathrm{O}\right.$ at $\left.1078 \mathrm{~cm}^{-1}\right)$ vibrations of $\mathrm{C}-\mathrm{O}-\mathrm{C}$ in urethane bonds and ether bonds (introduced by ether-based polyol). Higher amount of fatty acid dimer diamine in the mixture of chain extenders results in increase of peaks intensity for stretching vibration of carbonyl group in urea bond and stretching vibrations (ca. 2950, 2920 and $2870 \mathrm{~cm}^{-1}$ ) of methyl and methylene groups. As can be seen in Fig. 2 the bio-based diamine consist of aliphatic main chain and aliphatic side chains, so increasing of $\mathrm{C}-\mathrm{H}$ stretching vibrations intensity is obvious.

The chemical structure of bio-based diamine PRIAMINE 1071 (Fig. 5) and the two selected poly(etherurethane-urea)s, i.e. PEtUU-0.5BA and PEtUU-1BA, was investigated using ${ }^{1} \mathrm{H}$ NMR spectroscopy (Fig. 6.).
Fig. 4 FTIR spectra of prepared poly(ether-urethane) PEtU and poly(ether-urethaneurea)s i.e. PEtUM-0.5BA and PEtUM-1.0BA

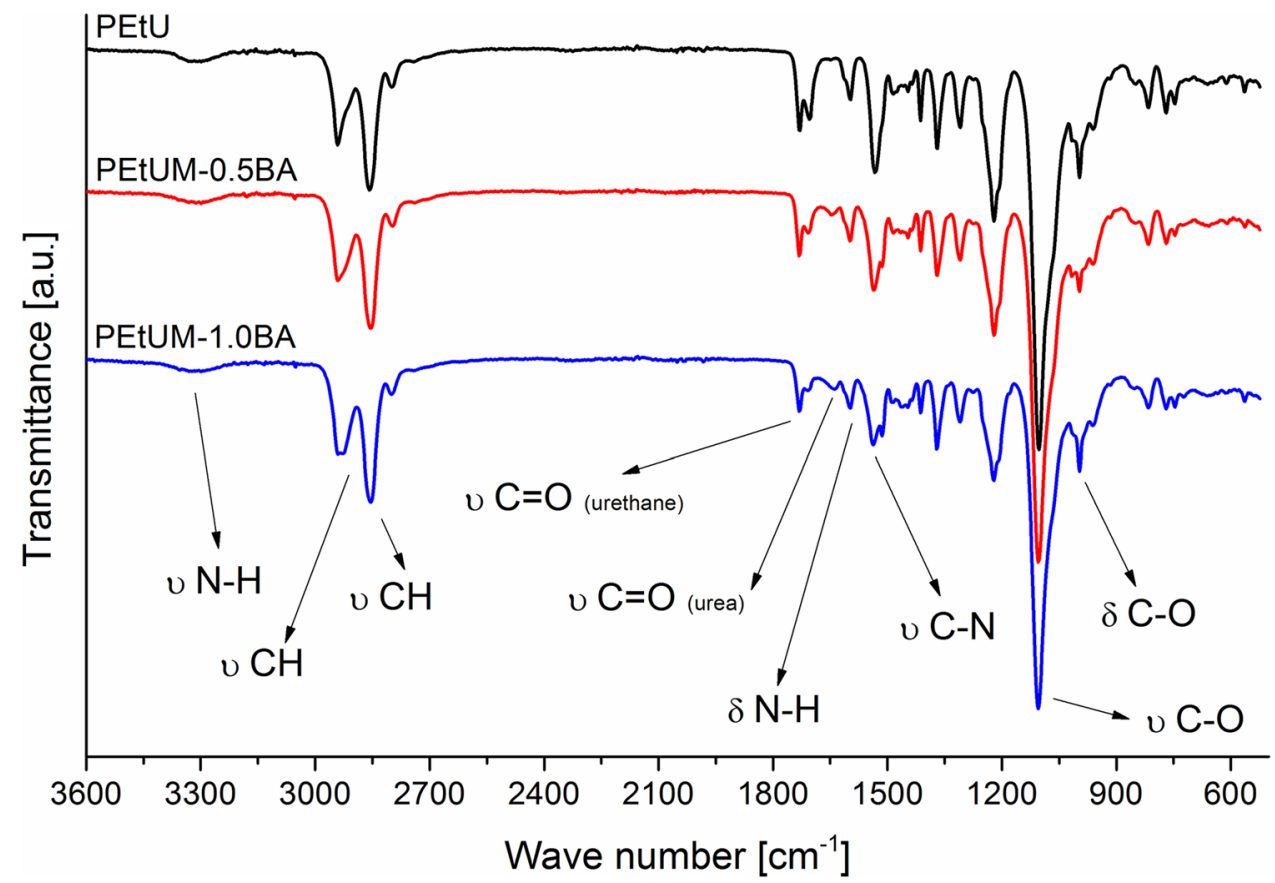




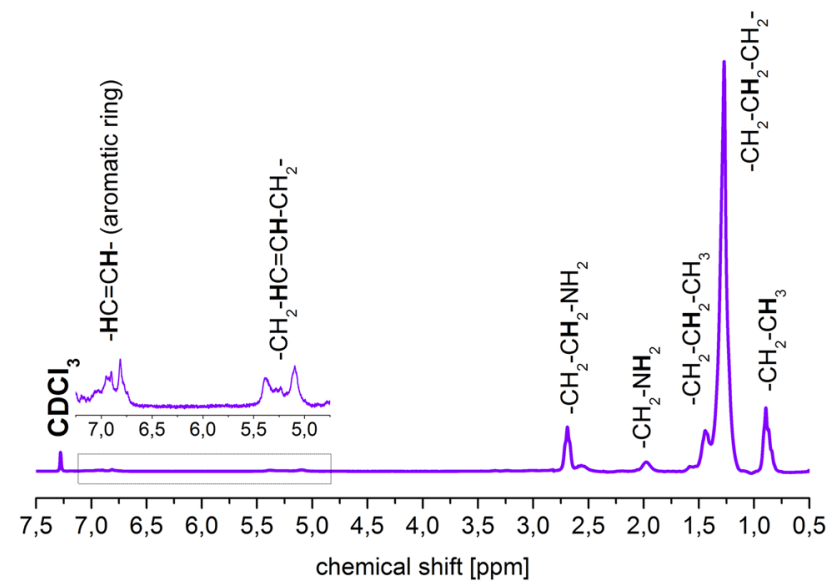

Fig. $5{ }^{1} \mathrm{H}$ NMR spectrum of bio-based diamine PRIAMINE 1071

The registered spectra are very similar, and the slight difference in the intensity of signals related to the methylene units $\left(-\mathrm{O}-\mathrm{CH}_{2}-\mathrm{CH}_{2}-\mathrm{CH}_{2}-\mathrm{CH}_{2}-\mathrm{O}-\right.$ and $\left(-\mathrm{O}-\mathrm{CH}_{2}-\mathrm{CH}_{2}-\mathrm{CH}_{2}-\mathrm{CH}_{2}-\mathrm{O}-\right)$ presented in PolyTHF and methyl $\left(\mathrm{H}_{3} \mathrm{C}-\mathrm{CH}_{2}-\mathrm{CH}_{2}-\right)$ andmethylene $\left(-\mathrm{CH}_{2}-\mathrm{CH}_{2}-\mathrm{CH}_{2}-\right)$ units in Priamine 1071 are observed. It is resulted from the different amount of both components, which were used for the synthesis of both analyzed materials.

The AFM analysis was used to observe the phase-separated microstructure of prepared poly(ether-urethane-urea) s. Figure 7 shows the AFM (height and three-dimensional) images obtained for PEtUM-0.25BA, PEtUM-0.5BA and PEtUM-1.0BA. It can be seen that prepared poly(urethaneurea)s present a phase separated microstructure, where the light regions are connected with soft segments and the dark corresponded to hard segments. The assignment of soft and hard segments to the light and dark regions in the AFM analysis was also presented by Saralegi et al. [3]. The height of soft regions decreases with increasing content of bio-based diamine in the mixture of chain extenders. Moreover, the surface morphology is more separated for PEtUM-1.0BA than in the case of PEtUM-0.25BA. This can be resulted from higher-content of soft segments based on bio-based diamine, which has higher molecular weight that 1,4-butanediol. The AFM results confirm that presence of bio-based diamine in the structure of poly(urethaneurea)s affecting the soft domain morphology, what can be resulted from different chemical nature of ether-based polyol and aliphatic-based diamine.

Results from dynamic mechanical analysis of poly(etherurethane-urea)s are shown in Figs. 8, 9, 10. For the all investigated samples, the storage modulus starts decrease around $-70^{\circ} \mathrm{C}$. The decrease in storage modulus and the maximum of damping factor at low temperatures are related to the glass transition temperature of soft segments $\left(\mathrm{T}_{\mathrm{g} \mathrm{sS}}\right)$ observed in the region from $-55.8^{\circ} \mathrm{C}$ (PEtUM-0.25BA) to $-48.0^{\circ} \mathrm{C}$ (PEtUM-1.0BA). Above glass transition of soft segments, storage modulus still decreasing to the melting temperature of soft segments $\left(\mathrm{T}_{\mathrm{m} \mathrm{sS}}\right)$ observed in the region

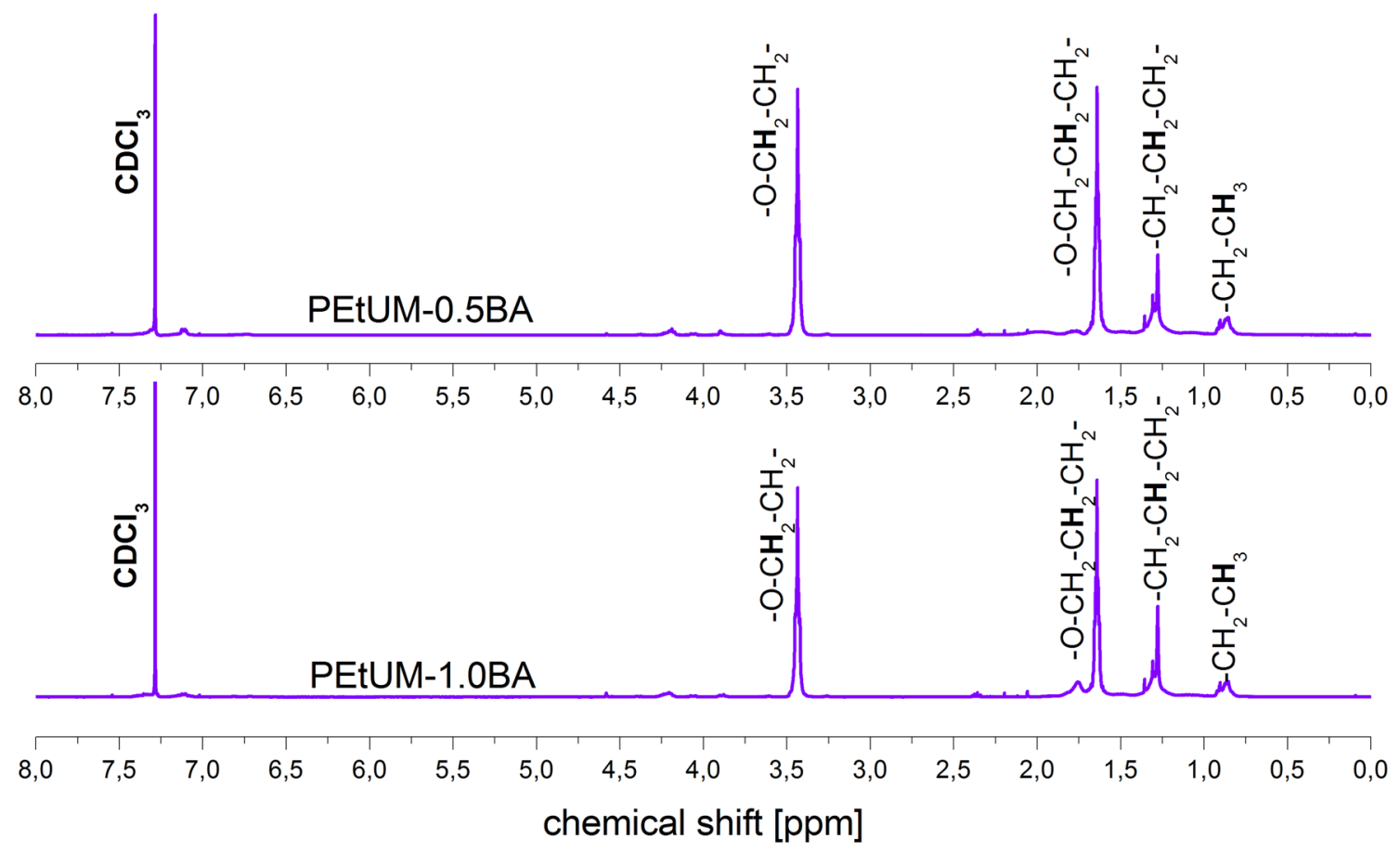

Fig. $6{ }^{1} \mathrm{H}$ NMR spectra of selected poly(ether-urethane-urea)s i.e. PEtUM-0.5BA and PEtUM-1.0BA 


\section{PEtUM-0.25BA}
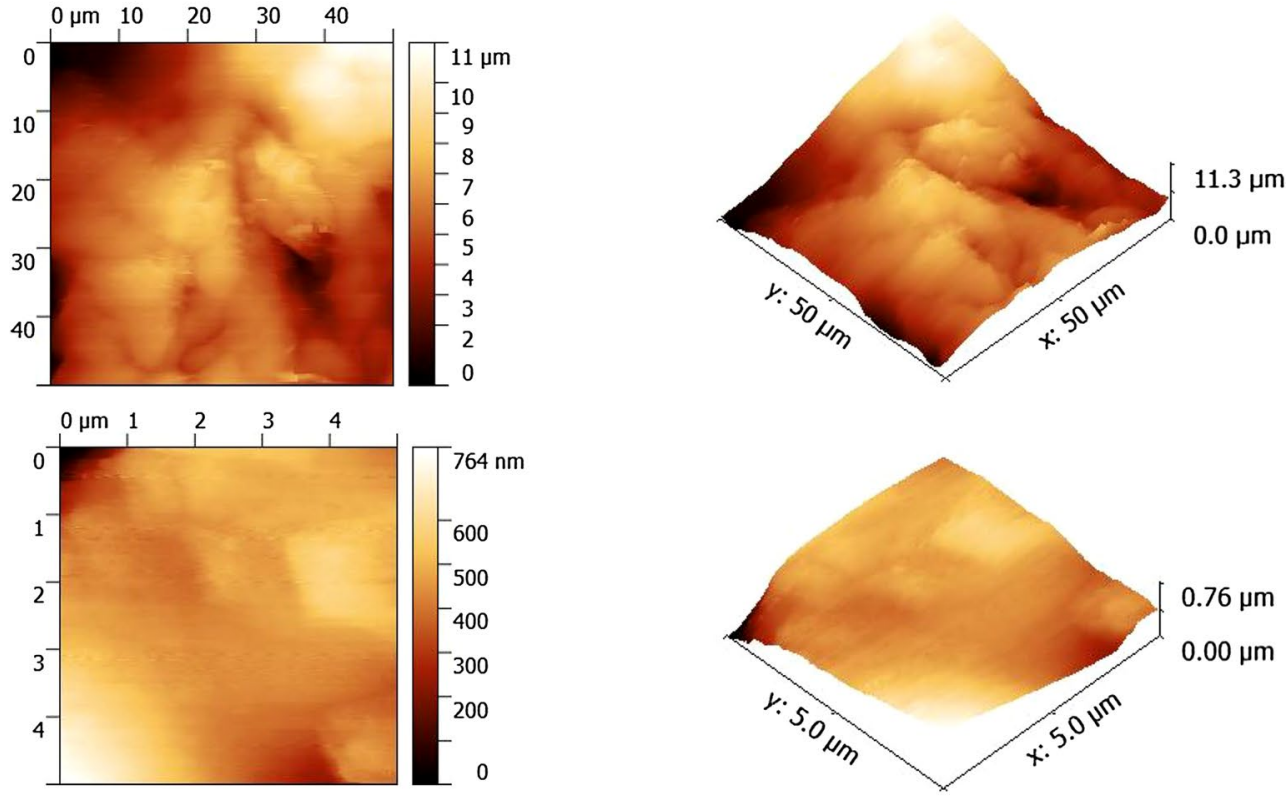

PEtUM-0.5BA
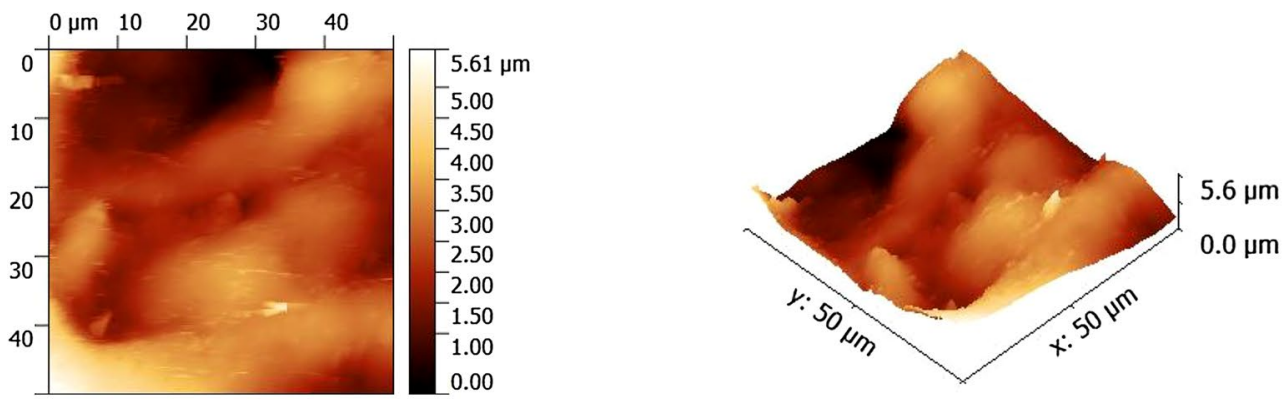

\section{PEtUM-1.0BA}
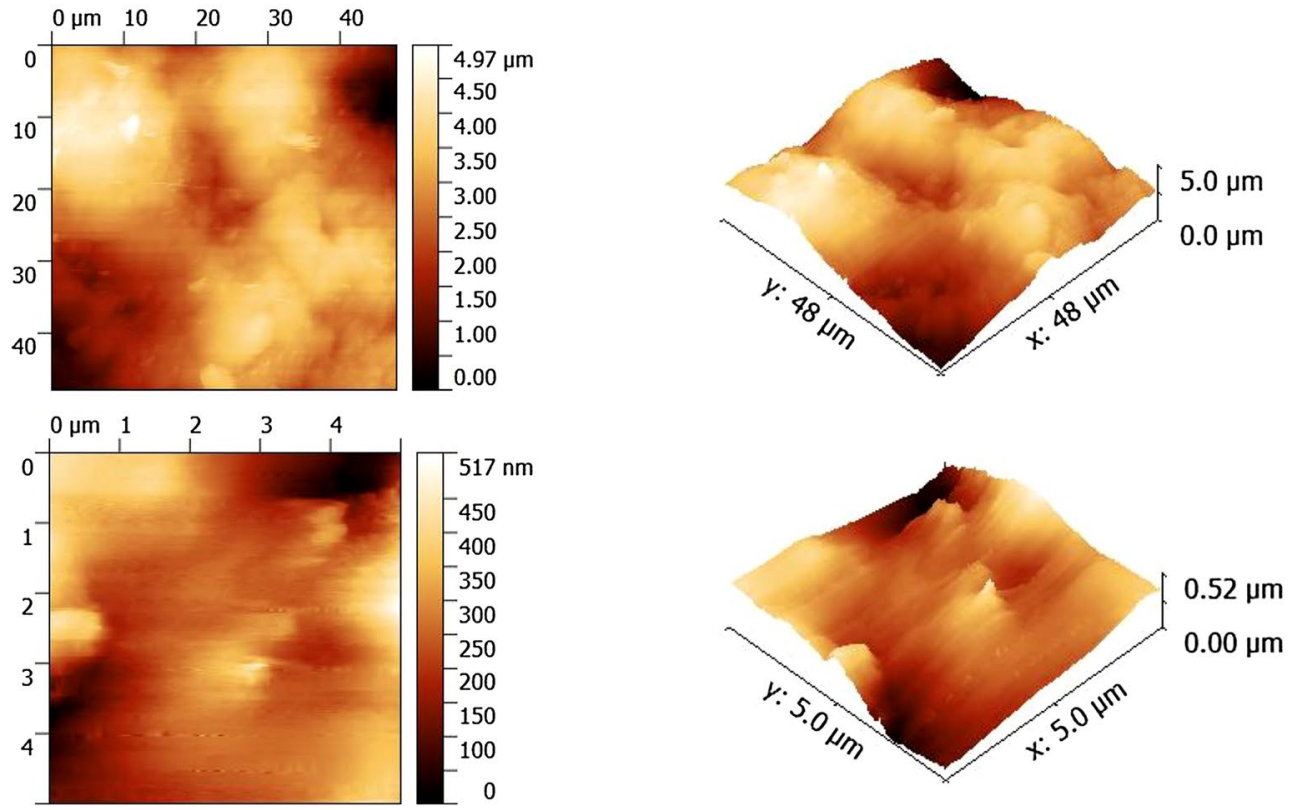

Fig. 7 Height (left) and three-dimensional (right) AFM images of selected bio-based poly(ether-urethane-urea)s 


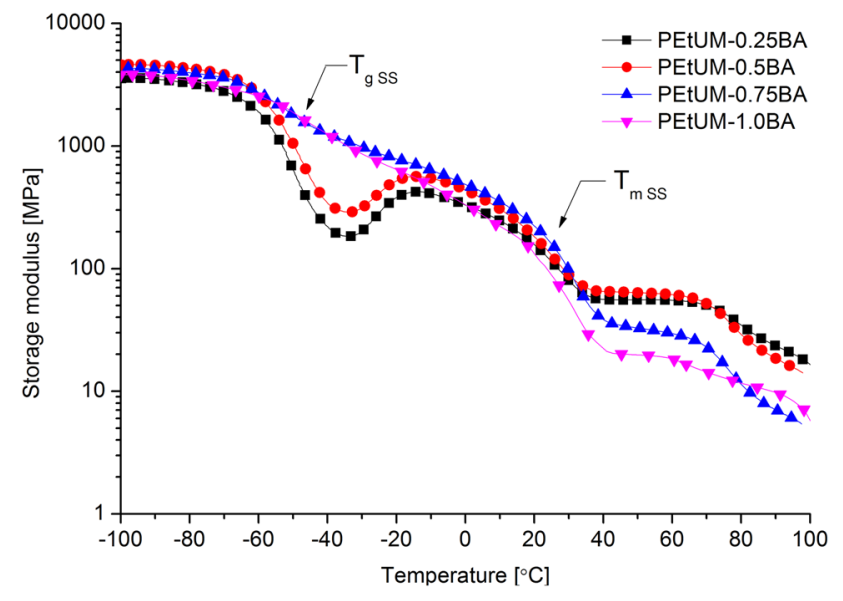

Fig. 8 Storage modulus vs. temperature for obtained poly(ether-urethane-urea)s

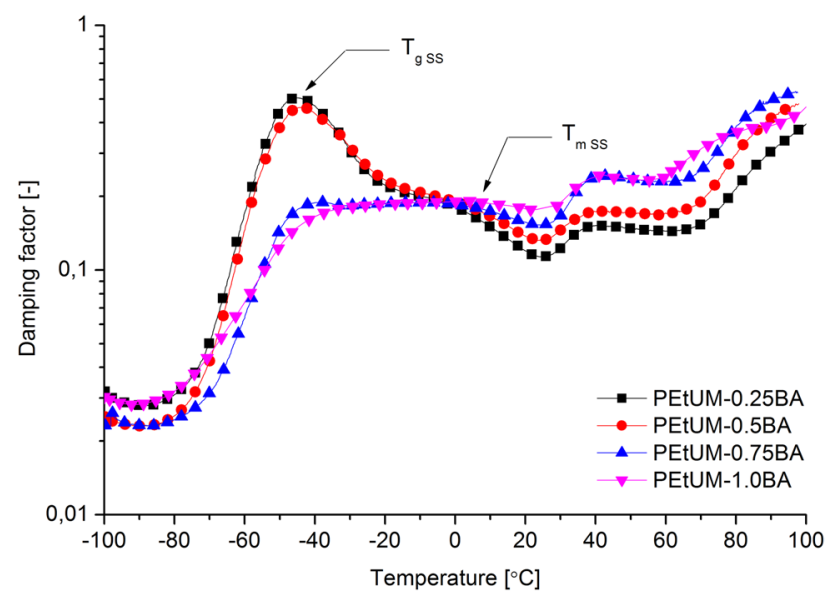

Fig. 9 Loss modulus versus temperature for obtained poly(ether-urethane-urea)s

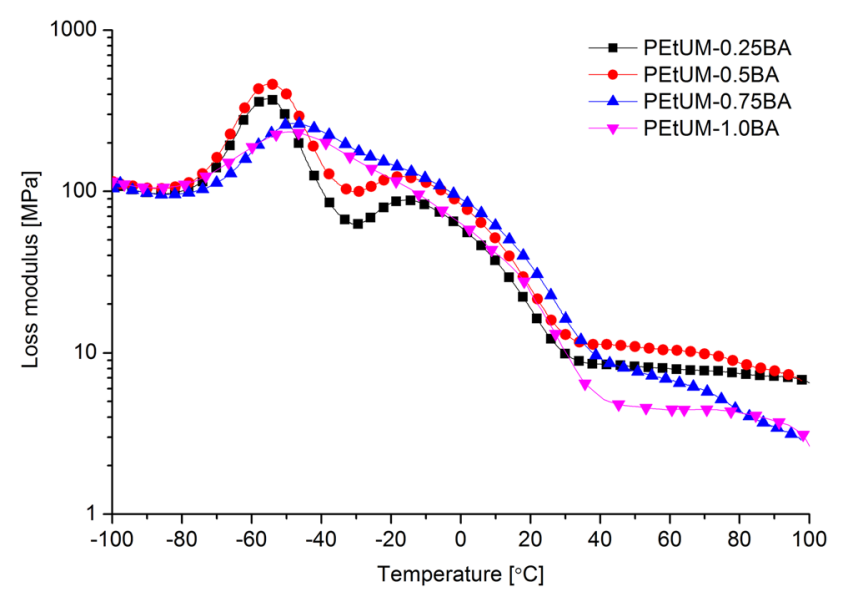

Fig. 10 Damping factor versus temperature for obtained poly(etherurethane-urea)s from $-7.2^{\circ} \mathrm{C}$ (PEtU) to $5.4^{\circ} \mathrm{C}$ (PEtUM-1.0BA). At this point the rate of decreasing is changing again. In the case of polyurethanes with the high content of soft segments $\mathrm{T}_{\mathrm{m} \text { SS }}$ is often observed and similar behavior was reported by other authors. The transition is connected with melting of crystalline ether-based soft segments, which is also observed in the case of poly(ether-urethane)s synthesized using high-molecular weight polyols $[3,23,24]$. The similar phenomena was also observed in our earlier work [22] connected with the synthesis of poly(ester-urethane-urea) $\mathrm{s}$ using a biobased diamine (PRIAMINE 1071), where the polyol [ $\alpha, \omega$-dihydroxy(ethylene-butylene adipate, POLIOS $55 / 20)$ ] with the high average molecular weight $(2000 \mathrm{~g} /$ mol) was used. The polyols in previous (POLIOS 55/20) and current (PolyTHF) work have the same average molecular weight but are different in the terms of chemical structure (i.e. ester- and ether-based polyol, respectively).

The improvement in storage modulus in the low temperatures (improvement of stiffness at low temperatures), especially visible in the case of PEtUM-0.75BA and PEtUM-1.0BA, is resulted from soft segment crystallinity. The crystalline regions of the soft domains act as reinforcing factor and result in mechanical integrity of the prepared poly(ether-urethane-urea)s. Similar behavior was observed by Korley et al. [24] in the case of semicrystalline segmented polyurethanes based on poly(ethylene oxide)poly(propylene oxide)-poly(ethylene oxide) macrodiol, 1,6-hexamethylene diisocyanate and 1,4-butanediol as a chain extender. The increasing of the storage modulus after the glass transition temperature can be also connected with the cold crystallization of the soft segments and the similar behavior was reported in the literature in the case of polyurethanes $[25,26]$.

Figure 11 shows DSC thermogram obtained for the poly(ether-urethane-urea) synthesized using only bio-based diamine as a curing agent (PEtUM-1.0BA). From the second heating curve two thermal transitions are visible, i.e. glass transition temperature of soft segments $\left(\mathrm{T}_{\mathrm{g} S \mathrm{~S}}\right)$ at $-50.9^{\circ} \mathrm{C}$ and melting transition of soft segments $\left(\mathrm{T}_{\mathrm{m} \mathrm{ss}}\right)$ at $25.1^{\circ} \mathrm{C}$. The board peak of melting transition is related to high content of soft phase (83.6 wt\%). The similar values of melting transition temperature and melting enthalpy were observed by Brzeska et al. [27], whose synthesized poly(ether-urethane) using poly(tetramethylene glycol) (2000 g/mol) and 4,4'diphenylmethane diisocyanates, and 1,4-butanediol as a chain extender, with the molar ratio PTMG:MDI:BDO equal 1:2:1.

The thermal stability of prepared poly(ether-urethane-urea)s was studied using TGA. The results for two selected materials, i.e. PEtUM-0.5BA and PEtUM1.0BA, are presented in Fig. 12 and in Table 3. The thermal degradation of polyurethanes depends of its chemical structure, and it is known that alkyl-based polyurethanes 


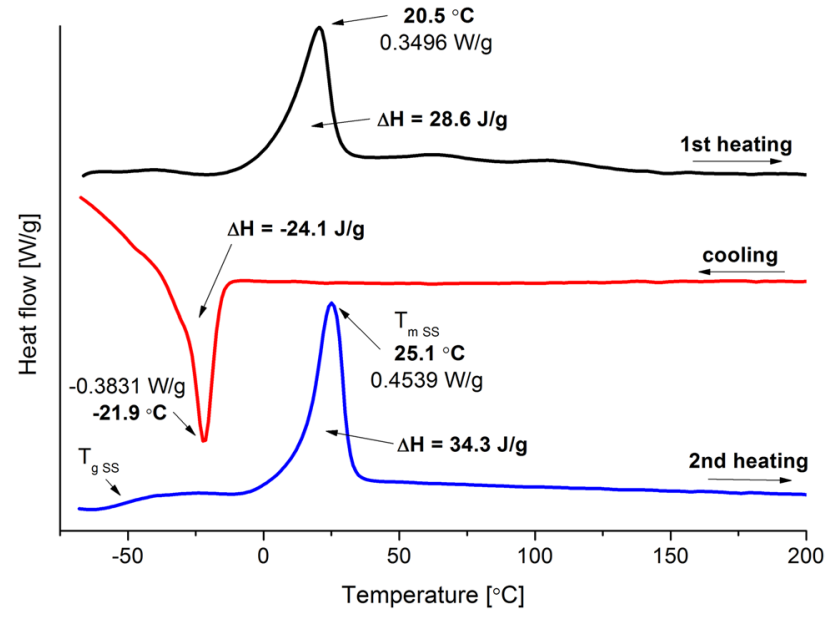

Fig. 11 DSC thermogram of synthesized poly(ether-urethane-urea) with the highest content of bio-based diamine (PEtUM-1.0BA)

exhibit higher thermal stability than aryl-based ones. The first main step, which occurs between 180 and $300^{\circ} \mathrm{C}$, is connected with thermal decomposition of hard segments due to presence of urethane bonds. The second step is connected with decomposition of soft segments [28]. The presence of urea bonds in the structure of poly(urethane-urea)s can improve thermal stability in comparison to similar polyurethanes [29]. The course of the weight loss curves of tested poly(urethane-urea) $\mathrm{s}$ are very similar. The small differences (slight higher thermal stability) are connected with higher content of long aliphatic chain bio-based diamine in the structure of prepared poly(ether-urethane-urea)s. The corresponding derivative curves consist of the small peak at around $366^{\circ} \mathrm{C}$ and the much bigger one at around $435^{\circ} \mathrm{C}$, which are connect with the decomposition of hard and soft segments, respectively. When the degree of phase-separation is insignificant, in the DTG curve only one peak is visible [30].

The tensile properties of obtained materials were shown in Figs. 13 and 14. The increasing amount of soft segments in the case of obtained poly(ether-urethaneurea)s is connected with decreasing of tensile strength and elongation at break. It can be also resulted from the structure of applied bio-based diamine. Presence of aliphatic side chains in the structure of bio-based diamine (Fig. 2) can caused reduction of polymer chains movements. Restriction of chains mobility resulted in faster failure of material than in case of poly(ether-urethane) obtained without using diamine (PEtU), which has the highest hard segments content. Similar behavior in the context of tensile strength and elongation at break was observed in our earlier work [22] in the case of poly(ester-urethaneurea)s obtained using 4,4'-diphenylemthane diisocyanate,

Table 3 Thermal stability of selected poly(ether-urethane-urea)s

\begin{tabular}{lllll}
\hline Poly(urethane-urea) & $\mathrm{T}_{5 \%}\left({ }^{\circ} \mathrm{C}\right)$ & $\mathrm{T}_{10 \%}\left({ }^{\circ} \mathrm{C}\right)$ & $\mathrm{T}_{50 \%}\left({ }^{\circ} \mathrm{C}\right)$ & $\mathrm{T}_{\max }\left({ }^{\circ} \mathrm{C}\right)$ \\
\hline PEtUM-0.25BA & 338.6 & 356.4 & 427.6 & 432.1 \\
PEtUM-0.5BA & 339.0 & 357.2 & 429.3 & 434.4 \\
PEtUM-0.75BA & 338.8 & 357.4 & 431.4 & 434.8 \\
PEtUM-1.0BA & 337.0 & 358.7 & 433.3 & 435.7 \\
\hline
\end{tabular}

Fig. 12 TG and DTG curves of selected poly(ether-urethaneurea)s

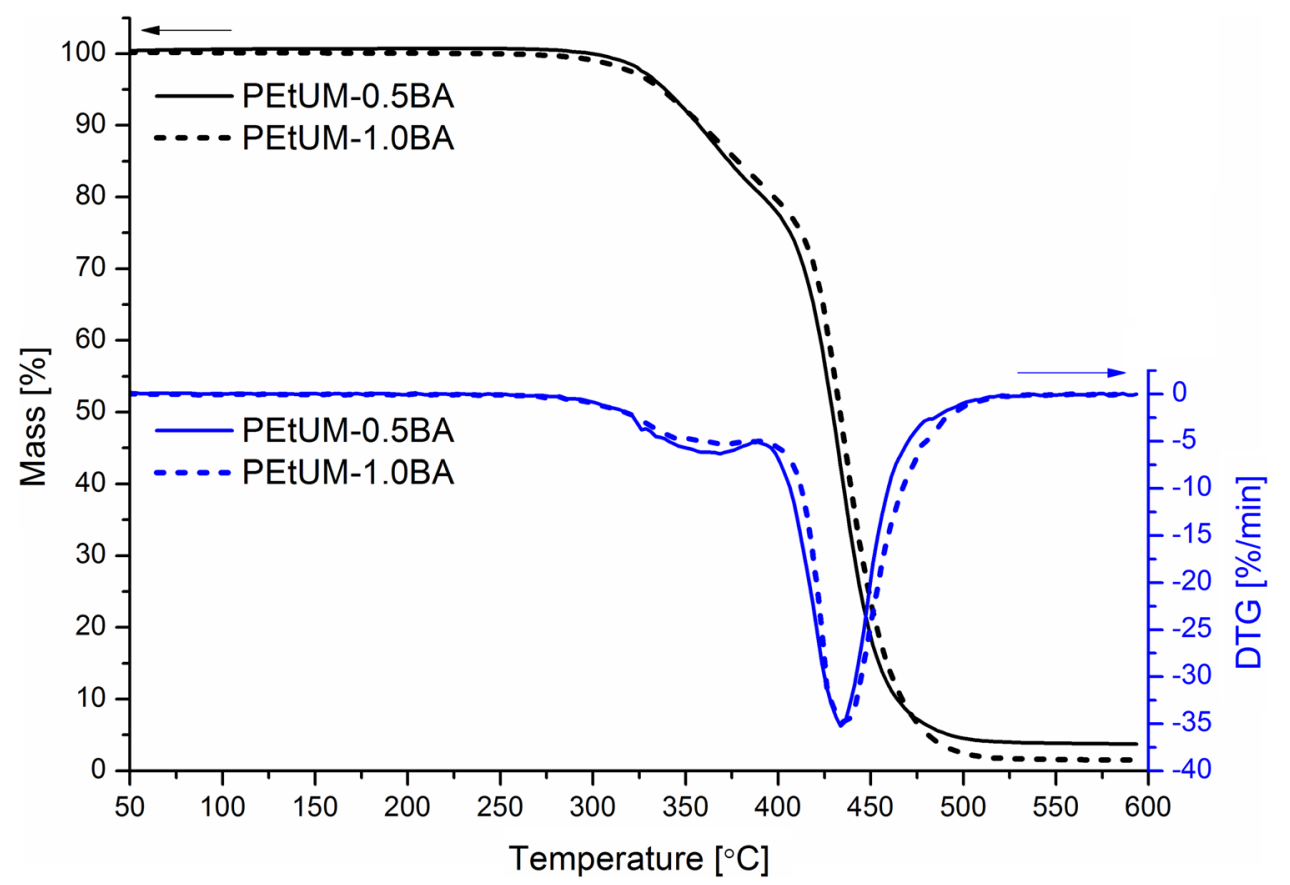



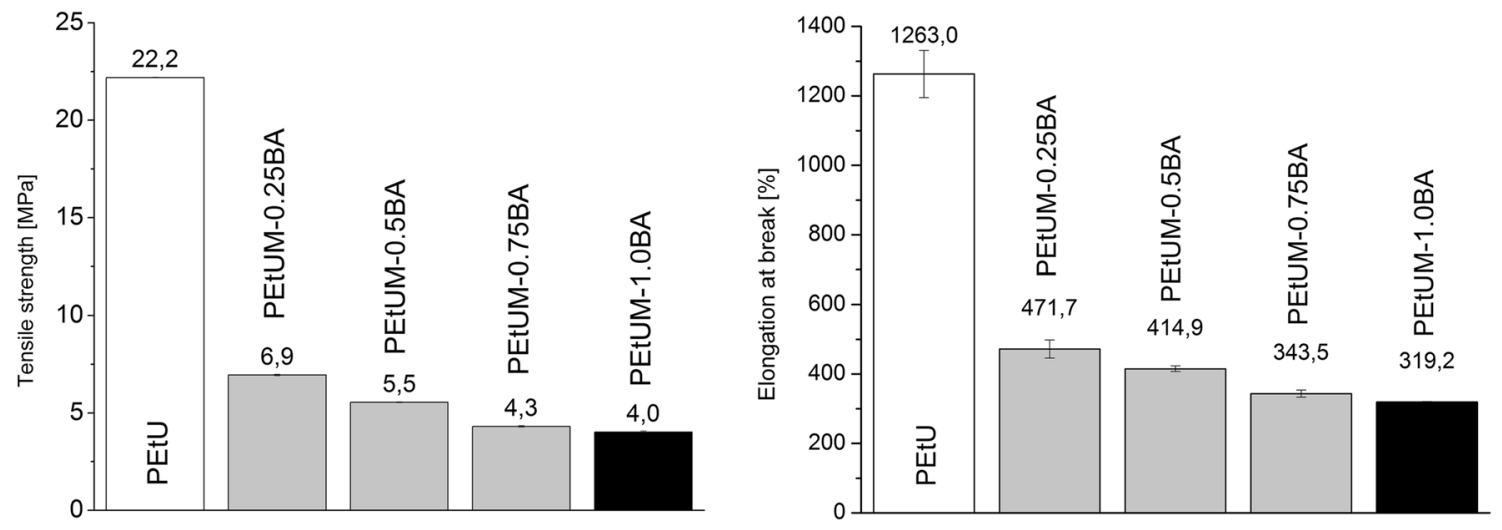

Fig. 13 Tensile strength and elongation at break of prepared poly(ether-urethane) and poly(ether-urethane-urea)s

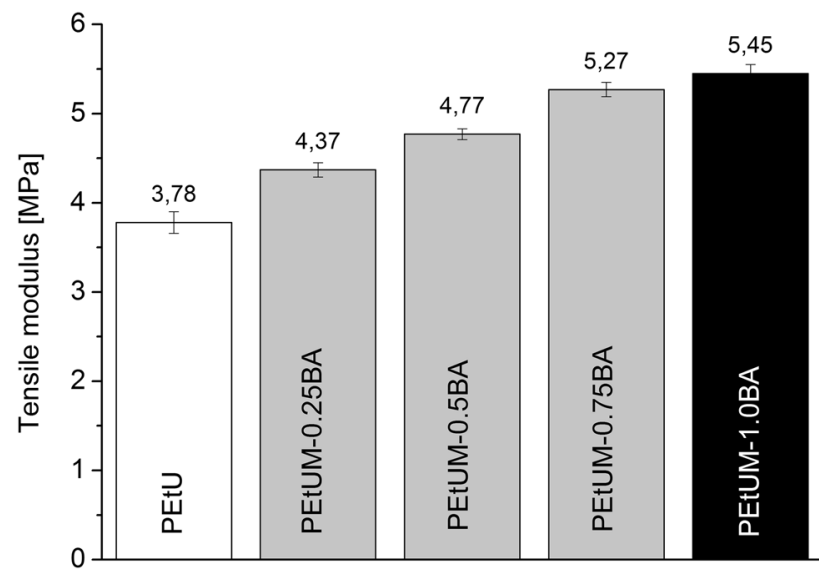

Fig. 14 Tensile modulus of prepared poly(ether-urethane) and poly(ether-urethane-urea)s

$\alpha, \omega$-dihydroxy(ethylene-butylene adipate) (POLIOS $55 / 20$ ), Priamine 1071 and BDO, which suggest that the tensile properties of poly(urea-urethane)s are strongly affected by the presence of bio-based diamine moieties in the chemical structure of the prepared polymers. Similar effect of fatty acids dimers on the mechanical behavior (e.g. low tensile strength) was observed by Bueno-Ferrer [31] in the case of biobased thermoplastic polyurethanes obtained from dimer fatty acids. The poly(ether-urethaneurea)s described in this work have higher tensile strength and elongation at break than poly(ester-urethane-urea) s described in our earlier work [22], which is probably resulted with better affinity of bio-based diamine moieties to ether-based soft segments.

The increasing content of soft segments generally is connected with decreasing of tensile strength and increasing of tensile modulus and elongation at break [3]. In the case of prepared poly(ether-urethane-urea)s, the situation is more complicated due to several factors related to applied chain extenders i.e. different molecular weight connected and different chemical structure i.e. different polarity, presence of aliphatic side chains. Presence of long aliphatic side chains in the structure of bio-based
CROSS-SECTION SURFACE

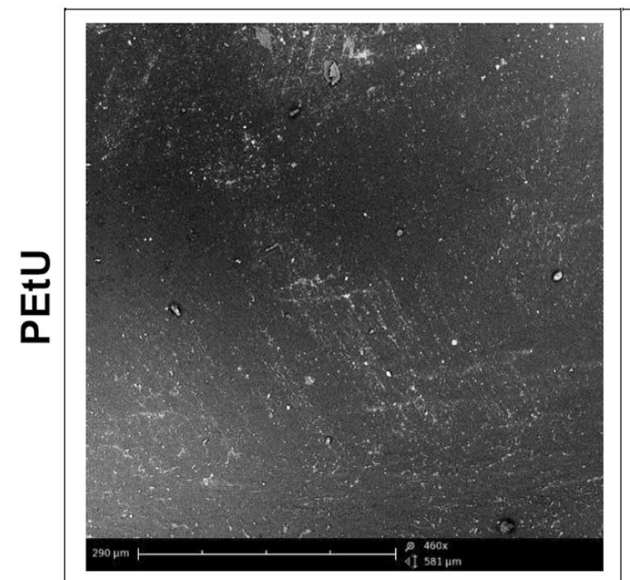

FRACTURE SURFACE AFTER STATIC TENSILE TEST
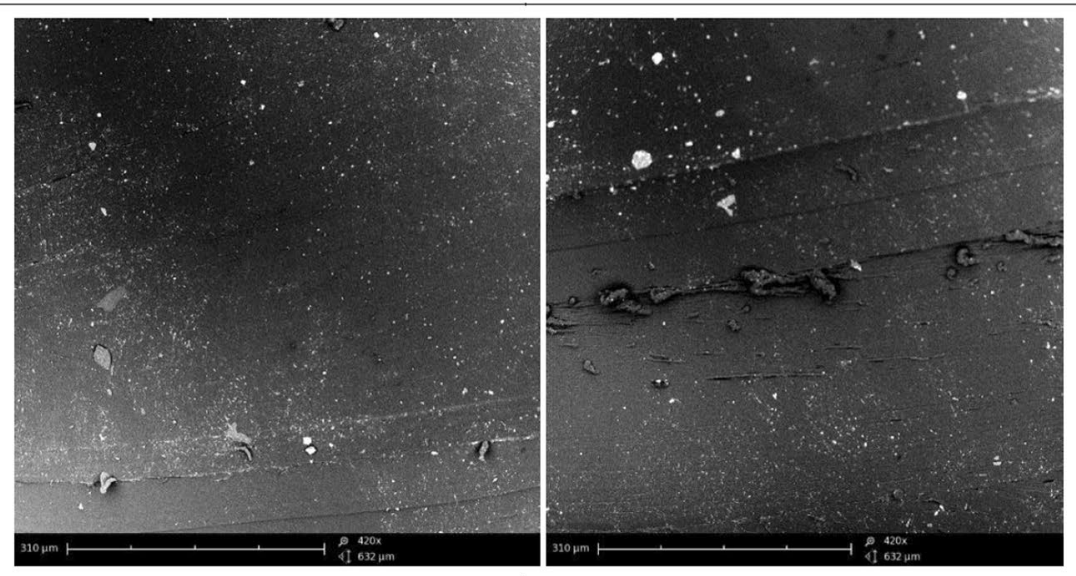

Fig. 15 Cross-section surface and fracture surface after static tensile test of prepared reference sample, i.e. poly(ether-urethane) 
diamine is also connected with increasing of tensile modulus (Fig. 12) observed with increasing of bio-based diamine content. The aliphatic side chains act as steric hindrance during poly(urea-urethane) chains movements and this result in higher stiffness (higher tensile modulus) of prepared bio-based materials.
The morphology of cross section and fracture surface after static tensile test was analyzed for all prepared polymers, and results are showed in Figs. 15, 16, 17. As can be seen the cross-section surfaces for all prepared materials are smooth and voids are absent. The analysis of fracture surface clearly indicate, that using of high molecular weight
CROSS-SECTION SURFACE
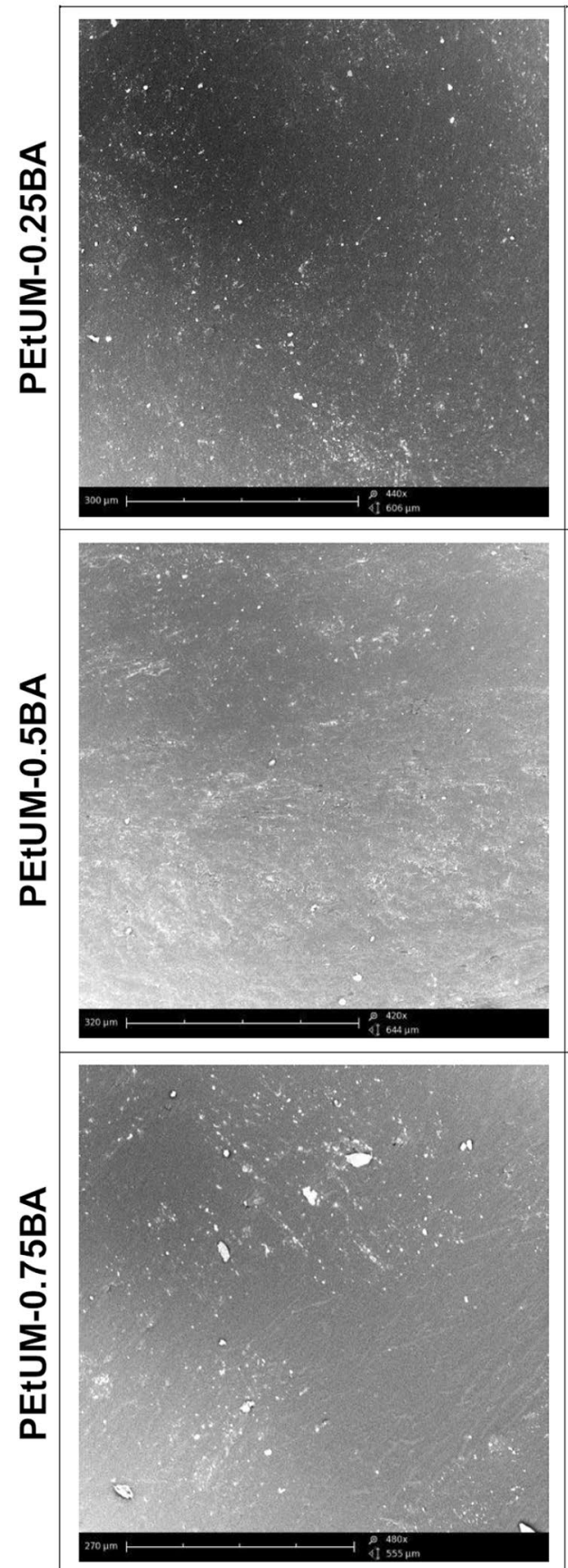

FRACTURE SURFACE AFTER STATIC TENSILE TEST
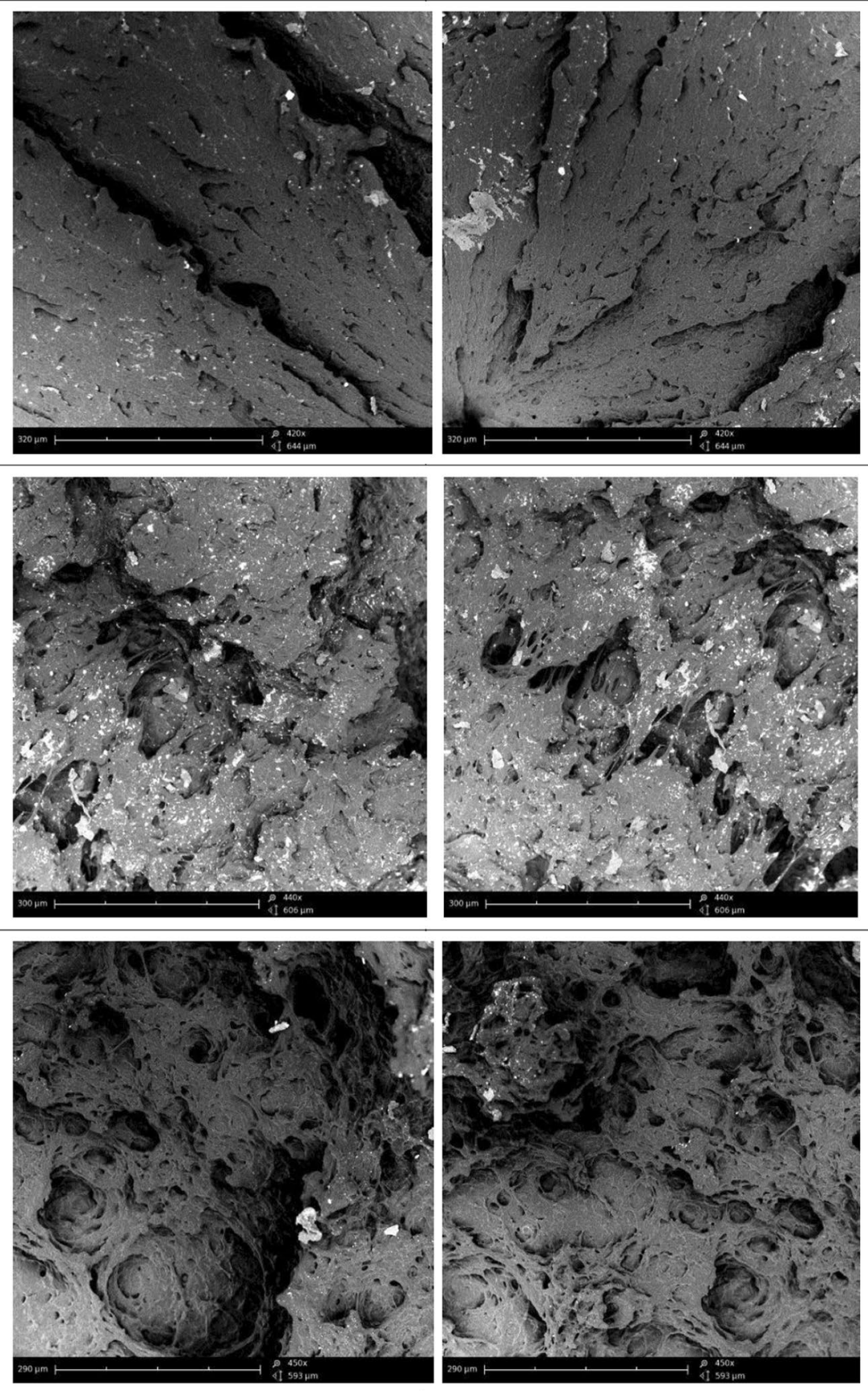

Fig. 16 Cross-section surface and fracture surface after static tensile test of prepared poly(ether-urethane-urea)s synthesized using mixture of curing agents 
CROSS-SECTION SURFACE

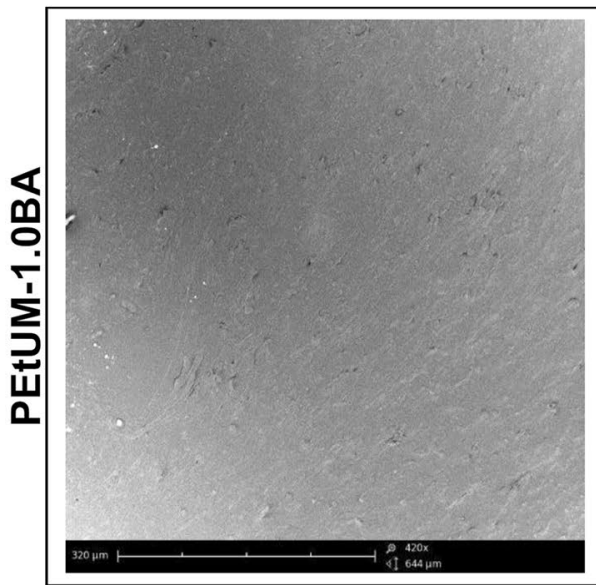

FRACTURE SURFACE AFTER STATIC TENSILE TEST

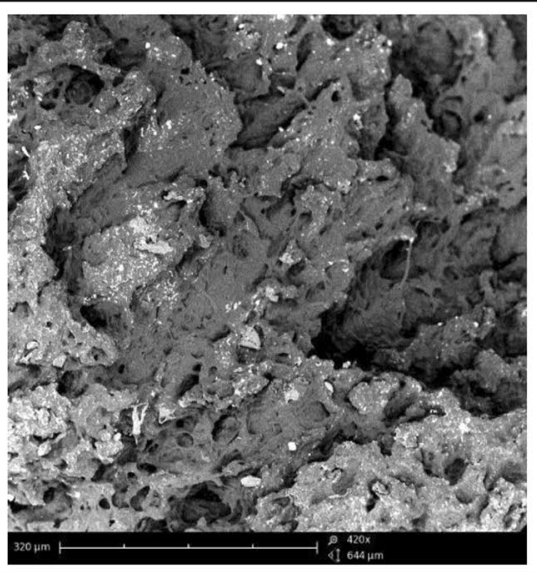

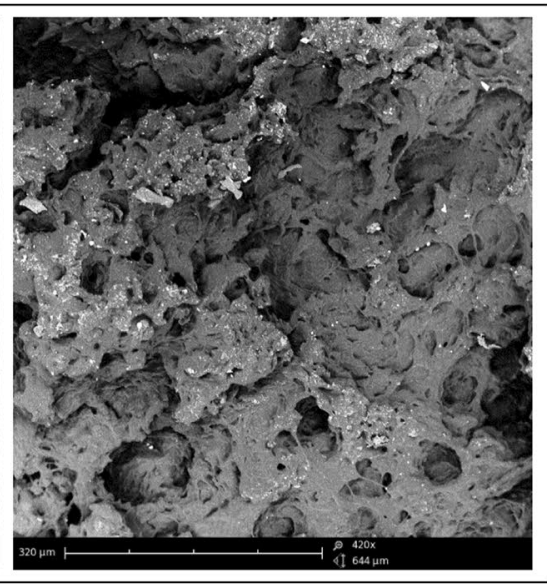

Fig. 17 Cross-section surface and fracture surface after static tensile test of prepared poly(ether-urethane-urea)s synthesized only bio-based diamine as a curing agent

bio-based diamine results in increasing of ductile nature of fracture formed during static tensile test. It is resulted from higher soft segments content due to presence of bio-based diamine, composed from long aliphatic main chain and side chains. The fracture surface is more deformed for PEtUM1.0BA in comparison to reference sample PEtU.

\section{Conclusions}

Partially bio-based poly(ether-urethane-urea)s were successful obtained using plant-based monomer. The diamine derivative of dimerized fatty acids (from vegetable oils, e.g. soybean or sunflower oil) was used as a curing agent for ether-urethane prepolymer. The bio-based content in the synthesized poly(urethane-urea)s is in the range from $5.1 \mathrm{wt} \%$ (PEtUM-0.25BA) to $18.0 \mathrm{wt} \%$ (PEtUM-1.0BA). Application of different amount of bio-based diamine caused change of soft segment content in the prepared materials, affected tensile properties. affected tensile properties of obtained poly(ether-urethane-urea)s. Observed behavior, i.e. increasing of tensile modulus connected with decreasing of tensile strength and elongation at break, is connected with the chemical structure of bio-based diamine (long aliphatic main chain with aliphatic side chains), which caused restriction of polymer chains movements. It was confirmed e.g. by results of dynamic mechanical analysis, due to observe increasing the glass transition temperature of soft segments.

Synthesis of poly(urethane-urea)s with using vegetable oil-based monomers (like Priamine 1071 which is an amine derivate of fatty acids dimers) are connected with trends of green chemistry. Suitable selection of components and their amounts will result in obtain of materials with competitive properties in comparison to petrochemical-based polymers. As was proved in this work, the application of plant-based building block in the synthesis of polymers resulted in obtain materials with diversified properties.

Acknowledgements We would also like to thank CRODA Company for supplying the bio-based diamine PRIAMINE 1071.

Open Access This article is distributed under the terms of the Creative Commons Attribution 4.0 International License (http:// creativecommons.org/licenses/by/4.0/), which permits unrestricted use, distribution, and reproduction in any medium, provided you give appropriate credit to the original author(s) and the source, provide a link to the Creative Commons license, and indicate if changes were made.

\section{References}

1. Zlatanić A, Lava C, Zhang W, Petrović ZS (2004) Effect of structure on properties of polyols and polyurethanes based on different vegetable oils. J Polym Sci B Polym Phys 42:809-819

2. Campanella A, Bonnaillie LM, Wool RP (2009) Polyurethane foams from soyoil-based polyols. J Appl Polym Sci 112:2567-2578

3. Saralegi A, Rueda L, Fernández-d'Arlas B, Mondragon I, Eceiza A, Corcuera MA (2013) Thermoplastic polyurethanes from renewable resources: effect of soft segment chemical structure and molecular weight on morphology and final properties. Polym Int 62:106-115

4. Zhang J, Tang JJ, Zhang JX (2015) Polyols prepared from ringopening epoxidized soybean oil by a castor oil-based fatty diol. Int J Polymer Sci. doi:10.1155/2015/529235

5. Luo X, Hu S, Zhang X, Li Y (2013) Thermochemical conversion of crude glycerol to biopolyols for the production of polyurethane foams. Bioresour Technol 139:323-329 
6. Jia LK, Gong LX, Ji WJ, Kan CY (2011) Synthesis of vegetable oil based polyol with cottonseed oil and sorbitol derived from natural source. Chin Chem Lett 22:1289-1292

7. Datta J, Głowińska E (2014) Effect of hydroxylated soybean oil and bio-based propanediol on the structure and thermal properties of synthesized bio-polyurethanes. Ind Crop Prod 61:84-91

8. Głowińska E, Datta J (2015) Structure, morphology and mechanical behaviour of novel bio-based polyurethane composites with microcrystalline cellulose. Cellulose 22:2471-2481

9. Hojabri L, Kong X, Narine SS (2009) Fatty acid-derived diisocyanate and biobased polyurethane produced from vegetable oil: synthesis, polymerization, and characterization. Biomacromolecules 10:884-891

10. Calvo-Correas T, Santamaria-Echart A, Saralegi A, Martin L, Valea A, Corcuera MA, Eceiza A (2015) Thermally-responsive biopolyurethanes from a biobased diisocyanate. Eur Polym J 70:173-185

11. Rojek P, Prociak A (2012) Effect of different rapeseed-oil-based polyols on mechanical properties of flexible polyurethane foams. J Appl Polym Sci 125:2936-2945

12. P.K.S. Pillai, Li S, Bouzidi L, Narine SS (2016) Metathesized palm oil: fractionation strategies for improving functional properties of lipid-based polyols and derived polyurethane foams. Ind Crop Prod 84:273-283

13. Saalah S, Abdullah LC, Aung MM, Salleh MZ, Awang Biak DR, Basri M, M.E.R. Jusoh (2015) Waterborne polyurethane dispersions synthesized from jatropha oil. Ind Crop Prod 64:194-200

14. Darroman E, Bonnot L, Auvergne R, Boutevin B, Caillol S (2015) New aromatic amine based on cardanol giving new biobased epoxy networks with cardanol. Eur J Lipid Sci Technol 117:178-189

15. Fache M, Darroman E, Besse V, Auvergne R, Caillol S, Boutevin B (2014) Vanillin, a promising biobased building-block for monomer synthesis. Green Chem 16:1987-1998

16. Cornille A, Froidevaux V, Negrell C, Caillol S, Boutevin B (2014) Thiol-ene coupling: an efficient tool for the synthesis of new biobased aliphatic amines for epoxy curing. Polymer 55:5561-5570

17. Hong J, Radojčić D, Ionescu M, Petrović ZS, Eastwood E (2014) Advanced materials from corn: isosorbide-based epoxy resins. Polym Chem 5:5360-5368

18. Wróblewska A, Zych A, Thiyagarajan S, Dudenko D, van Es D, Hansen MR, Koning C, Duchateau R, Jasińska-Walc L (2015) Towards sugar-derived polyamides as environmentally friendly materials. Polym Chem 6:4133-4143

19. Maisonneuve L, More AS, Flotran S, Alfos C, Robert F, Landais Y, Tassaing T, Grau E, Cramail H (2014) Novel green fatty acid-based bis-cyclic carbonates for the synthesis of isocyanatefree poly(hydroxyurethane amide)s. RSC Adv 4:25795-25803

20. Stemmelen M, Lapinte V, Habas JP, Robin JJ (2015) Plant oilbased epoxy resins from fatty diamines and epoxidized vegetable oil. Eur Pol J 68:536-545

21. Stemmelen M, Pessel F, Lapinte V, Caillol S, Habas JP, Robin JJ (2011) A fully biobased epoxy resin from vegetable oils: from the synthesis of the precursors by thiol-ene reaction to the study of the final material. J Polym Sci A Polym Chem 49:2434-2444

22. Włoch M, Datta J (2016) Synthesis, structure and properties of poly(ester-urethane-urea)s synthesized using biobased diamine. J Renew Mater 4:72-77

23. Prisacariu C, Scortanu E, Airinei A, Agapie B, Iurzhenko M, Mamunya YP (2011) New developments in thermoplastic polyurethanes of variable crystallinity: sensitivity of cyclic stressstrain response to chemical structure. Procedia Eng 10:446-454

24. Korley LTJ, Pate BD, Thomas EL, Hammond PT (2006) Effect of the degree of soft and hard segment ordering on the morphology and mechanical behavior of semicrystalline segmented polyurethanes. Polymer 47:3073-3082

25. Czech P, Okrasa L, Mechin F, Boiteux G, Ulanski J (2006) Investigation of the polyurethane chain length influence on the molecular dynamics in networks crosslinked by hyperbranched polyester. Polymer 47:7207-7215

26. Strankowski M, Włodarczyk D, Piszczyk Ł, Strankowska J (2016) Thermal and mechanical properties of microporous polyurethanes modified with reduced graphene oxide. Int J Polym Sci. doi: $10.1155 / 2016 / 8070327$

27. Brzeska J, Dacko P, Janeczek H, Kowalczuk M, Janik H, Rutkowska M (2009) Properties of polyurethanes with synthetic poly([R,S]-3-hydroxybutyrate) in soft segment. Technical Trans Mech 3:37-41

28. Navarro-Baena I, Arrieta MP, Mujica-Garcia A, Sessini V, Lopez D, Kenny JM, Peponi L (2015) Thermal degradation effects on polyurethanes and their nanocomposites. In: A. Tiwari, Raj B (ed) Reactions and mechanisms in thermal analysis of advanced materials. Scrivener Publishing, Beverly, p 165-189

29. Oprea S (2012) Synthesis and characterization of linear and crosslinked poly(urethane urea) elastomers with triazine moieties in the main chain. Polym Bull 68:1271-1285

30. Prociak A, Rokicki G, Ryszkowska J (eds) (2014) Polyurethane materials. PWN, Warsaw

31. Bueno-Ferrer C, Hablot E, Del Carmen Garrigos M, Bocchini S, Averous L, Jimenez A (2012) Relationship between morphology, properties and degradation parameters of novative biobased thermoplastic polyurethanes obtained from dimer fatty acids. Polym Degrad Stab 97:1964-1969 